Original research article

\title{
Prevalence of hypertension and predictive factors of self-efficacy among elderly people with hypertension in institutional-based rehabilitation in Indonesia
}

\author{
Tantut Susanto*, Hanny Rasny, Latifa Aini Susumaningrum, Rismawan Adi Yunanto, \\ Kholid Rosyidi Muhammad Nur \\ University of Jember, Faculty of Nursing, Department of Community, Family, and Gerontic Health Nursing, Jember, Indonesia
}

\begin{abstract}
Aim: Identification of hypertension factors among elderly people is expected to form appropriate nursing interventions to improve the self-efficacy of patients by modifying factors affecting the blood pressure of elderly people with hypertension. The aim of this study is to investigate the prevalence of hypertension and predictive factors of self-efficacy among elderly people with hypertension in institutionbased rehabilitation (IBR) in Indonesia.

Methods: An IBR cross-sectional study was conducted, involving 64 elderly people selected through random sampling. Research data were collected using a structured questionnaire and standard protocol, employing a stethoscope and sphygmomanometer to measure blood pressure. The data were then analysed using descriptive and comparative statistics, as well as multivariate linear regression analyses.

Results: The prevalence of systolic and diastolic hypertension among elderly people who lived in the IBR were $31.30 \%$ and $45.30 \%$, respectively. The predictors of self-efficacy of the elderly with regard to systolic hypertension were spiritual activity, length of stay, education, the occupation of the elderly before entering the rehabilitation, and dementia; while daily activities, risk of falling, pain, and depression anxiety and stress become significant predictors of self-efficacy in elderly people with diastolic hypertension.

Conclusion: This study provides new evidence that signifies the current burden of hypertension and the critical factors of self-efficacy for uncontrolled hypertension among the elderly in the IBR. The study suggests that health-promotion programs should be developed to modify factors of hypertension among elders of IBR in Indonesia.
\end{abstract}

Keywords: Blood pressure; Elderly; Hypertension; Institution-based rehabilitation; Self-efficacy

\section{Introduction}

Changes in the aging process will affect the body's physical functioning which is commonly associated with hypertension problems (Son and Won, 2017). The prevalence of hypertension in Indonesia is $45.9 \%$ in the age group of 55-64 years, $57.6 \%$ in the age group of $65-74$ years, and $63.8 \%$ in the age group of 75 years and above (Badan Penelitian dan Pengembangan Kesehatan, 2013). As the age increases, the blood pressure increases and hypertension is generally considered a normal condition in the elderly (Lee and Park, 2017). To maintain the blood pressure of elderly people at $140 / 90 \mathrm{mmHg}$ is very difficult (Currie and Delles, 2018). This is associated with various factors such as age, body weight (obese), lower level of education, an unbalanced dietary pattern, regular drinking and non-comorbidities (Yang et al., 2017). Therefore, behavior management (Douglas and Howard. 2015) and self-efficacy (Sol et al., 2006) are needed for maintaining blood pressure and its factors among the elderly to keep the hypertension problem under control.
Attitudes and views of hypertension (Elder et al., 2012) impacts on complications, progression of illness, improper care, and premature death among elders (Yu et al., 2001). Selfcare management is urgently needed for controlling the blood pressure of elderly people (Friedberg et al., 2015). Health behavior management (Martin et al, 2008) and health promotion (Li and Zhang, 2013) positively correlated with the elderly's self-efficacy related to hypertension. Furthermore, self-efficacy is an important factor in relation to hypertension self-care behaviors (Warren-Findlow et al., 2012). Therefore, self-efficacy is necessary for controlling or altering factors affecting blood pressure in elderly people with hypertension.

Previous research has shown that mentoring and training programs with self-efficacy can improve the health behavior and quality of life of hypertensive patients (Eom and Lee, 2017), while an intervention program in the community is able to improve the self-efficacy and health behavior and to reduce the modifiable cardiovascular risk factors of elderly people with hypertension (Yang et al., 2016). Previous studies have shown the role of self-efficacy in decreasing salt intake (Irwan et al., 2016), reducing depression, encouraging medica-

\footnotetext{
* Author for correspondence: Tantut Susanto, University of Jember, Faculty of Nursing, Department of Community, Family, and Gerontic Health Nursing, Jl. Kalimantan 37, Jember, Jawa Timur, 68121 Indonesia; e-mail: tantut_s.psik@unej.ac.id http://doi.org/10.32725/kont.2018.007

Submitted: 2018-07-03 • Accepted: 2018-11-02 • Prepublished online: 2019-01-11 
tion adherence (Son and Won, 2017), and improving the regularity of exercise (Jewpattanakul, 2012) and physical activities (Martin et al., 2008). The health management of the elderly hypertensive is determined by the existence of self-efficacy in modifying any factor associated with blood pressure control.

This study included self-efficacy among elderly patients with hypertension in Indonesia. With the identification of these factors, it is expected that appropriate nursing interventions can be designed to improve the self-efficacy of patients by modifying factors which affect the blood pressure of elderly people with hypertension. Therefore, the objective of the study was to investigate the prevalence of hypertension and the predictive factors of self-efficacy among the elderly with hypertension in institution-based rehabilitation in Indonesia.

\section{Materials and methods}

\section{Sample and setting}

An institutional rehabilitation-based cross sectional study was conducted. After this, we used a convenience sampling. Approximately, 64 elders participated in this study. The participants were selected using a simple random sampling technique. The criteria for the participants were as follows: (1) age $\geq 55$ years (people aged over 55 years are classified as early elderly in Indonesian context); (2) living in institutional care; (3) having the ability to communicate verbally with the researcher and understand all of the questions and (4) signing the consent form. We excluded elderly people with mental disorders (schizophrenia) and psychological dysfunction.

\section{Data collection}

The data was collected for one month (in March 2018). We measured the characteristics of the participants as follows: age (years), gender (male vs. female), length of stay in institutional care (years), ethnicity (Jawa, Madura, or Mixed), education (not attending, elementary school, junior high school, senior high school, and university/college), occupation before entering the institution (public government, entrepreneur, farmer/seller), and marital status (single, married, divorced, widowed).
We also measured the elderly measurement status, including Katz Index of Independence in Activities of Daily Living (ADL) (Wallace and Shelkey, 2000), Short Portable Mental Status Questionnaire (SPMSQ) (Pfeiffer, 1975), The Mini Mental State Examination (MMSE) (Ridha and Bossor, 2005), APGAR Family (Smilkstein, 1978), Beck's Depression Scales (BDS) (Beck et al., 1961), Mini Cognitive (Borson et al., 2003), Daily Spiritual Experience Scale (DSES) (Krebs et al., 2007), Depression Anxiety Stress Scale 42 (DASS-42) (Lovibond and Lovibond, 1995), Depression Anxiety Stress Scale 14 (DASS-14) (Wise et al., 2017), Pain Numeric Rating Scale (NRS) (Krebs et al., 2007), Morse Fall Scale (Morse et al., 1989), and General Self-efficacy (Schwarzer and Jerusalem, 1995).

To measure blood pressure, we used a standard protocol employing a stethoscope and sphygmomanometer. In this study, we controlled blood pressure by maintaining systolic blood pressure below $140 \mathrm{mmHg}$ and diastolic blood pressure below $90 \mathrm{mmHg}$ (Currie and Delles, 2018). Uncontrolled hypertension was defined as systolic blood pressure $\geq 140 \mathrm{mmHg}$ or diastolic blood pressure $\geq 90 \mathrm{mmHg}$ based on the mean value measured.

\section{Analysed data}

All research data were analysed using the IBM Statistical Package for Social Sciences software program, version 22.0. Statistic descriptive was used to determine the characteristics of the participants with mean and standard deviation (for numeric data) and percentage (for categorical data). Firstly, we tested the normality of the distribution of the data. Then, Chi-square tests and $t$-tests of independence were used to compare categorical and continuous variables in systolic and diastolic blood pressure. To determine factors related to self-efficacy, a linear regression analysis was used to examine the relationship between several factors of elderly people and the self-efficacy of elderly people with hypertension. A $p$-value $<0.05$ was considered statistically significant.

\section{Results}

The prevalence of systolic and diastolic hypertension among the elderly who lived in the institutional rehabilitation were $31.30 \%$ and $45.30 \%$ respectively (Table 1 ).

Table 1. Correlation between the characteristics of participants, health status and blood pressure $(n=64)$

\begin{tabular}{|c|c|c|c|c|c|c|c|c|c|}
\hline \multirow[t]{2}{*}{ Variable } & Total & \multicolumn{2}{|c|}{ Systolic blood pressure } & \multicolumn{6}{|c|}{ Diastolic blood pressure } \\
\hline & $n(\%)$ & $<150 \mathrm{mmHg}$ & $>150 \mathrm{mmHg}$ & $t / \chi^{2}$ & $p$-value & $<90 \mathrm{mmHg}$ & $>90 \mathrm{mmHg}$ & $t / \chi^{2}$ & $p$-value \\
\hline \multicolumn{10}{|l|}{ Age (year) } \\
\hline$M \pm S D$ & $71.86 \pm 9.94$ & $71.11 \pm 8.95$ & $73.50 \pm 11.92$ & -0.889 & 0.378 & $70.43 \pm 10.28$ & $73.59 \pm 9.40$ & -1.271 & 0.208 \\
\hline \multicolumn{10}{|l|}{ Gender } \\
\hline Male & $38(59.40)$ & $26(59.10)$ & $12(60.00)$ & 0.000 & 1.000 & $21(60.00)$ & $17(58.60)$ & 0.000 & 1.000 \\
\hline Female & $26(40.60)$ & $18(40.90)$ & $8(40.00)$ & & & $14(40.00)$ & $12(41.40)$ & & \\
\hline \multicolumn{10}{|l|}{ Length of stay (year) } \\
\hline$M \pm S D$ & $3.70 \pm 4.44$ & $4.16 \pm 5.17$ & $2.70 \pm 1.84$ & 1.657 & 0.103 & $4.43 \pm 5.59$ & $2.83 \pm 2.24$ & 1.552 & 0.127 \\
\hline \multicolumn{10}{|l|}{ Ethnicity } \\
\hline Madura & $14(21.90)$ & $9(20.50)$ & $5(25.00)$ & 0.730 & 0.694 & $10(28.60)$ & $4(13.80)$ & 5.084 & 0.079 \\
\hline Jawa & $44(68.80)$ & $30(68.20)$ & $14(70.00)$ & & & $20(57.10)$ & $24(82.80)$ & & \\
\hline Etc & $6(9.40)$ & $5(11.40)$ & $1(5.00)$ & & & $5(14.30)$ & $1(3.40)$ & & \\
\hline \multicolumn{10}{|l|}{ Education } \\
\hline Did not attend & $16(25.00)$ & $8(18.20)$ & $8(40.00)$ & 4.968 & 0.291 & $9(25.70)$ & $7(24.10)$ & 0.771 & 0.942 \\
\hline Elementary school & $24(37.50)$ & $18(40.90)$ & $6(30.00)$ & & & $14(40.00)$ & $10(34.50)$ & & \\
\hline Junior high school & $8(12.50)$ & $5(11.40)$ & $3(15.00)$ & & & $4(11.40)$ & $4(13.80)$ & & \\
\hline Senior high school & $13(20.30)$ & $10(22.70)$ & $3(15.00)$ & & & $7(20.00)$ & $6(20.70)$ & & \\
\hline University college & $3(4.70)$ & $3(6.80)$ & 0 & & & $1(2.90)$ & $2(6.90)$ & & \\
\hline
\end{tabular}




\section{Table 1 (Continued)}

\begin{tabular}{|c|c|c|c|c|c|c|c|c|c|}
\hline \multirow[t]{2}{*}{ Variable } & \multirow{2}{*}{$\begin{array}{c}\text { Total } \\
n(\%)\end{array}$} & \multicolumn{2}{|c|}{ Systolic blood pressure } & \multicolumn{6}{|c|}{ Diastolic blood pressure } \\
\hline & & $<150 \mathrm{mmHg}$ & $>150 \mathrm{mmHg}$ & $t / \chi^{2}$ & $p$-value & $<90 \mathrm{mmHg}$ & $>90 \mathrm{mmHg}$ & $t / \chi^{2}$ & $p$-value \\
\hline \multicolumn{10}{|c|}{ Occupation before entrance } \\
\hline Public government & $3(4.70)$ & $3(6.80)$ & 0 & 3.759 & 0.153 & 0 & $3(10.30)$ & 4.736 & 0.094 \\
\hline Enterpreneurship & $13(20.30)$ & $11(25.00)$ & $2(10.00)$ & & & $9(25.70)$ & $4(13.80)$ & & \\
\hline Others & $48(75.00)$ & $30(68.20)$ & $18(90.00)$ & & & $26(74.30)$ & $22(75.90)$ & & \\
\hline \multicolumn{10}{|l|}{ Marital status } \\
\hline Single & $7(10.90)$ & $7(15.90)$ & 0 & 4.956 & 0.175 & $6(17.10)$ & $1(3.40)$ & 4.213 & 0.239 \\
\hline Married & $24(37.50)$ & $16(36.40)$ & $8(40.00)$ & & & $13(37.10)$ & $11(37.90)$ & & \\
\hline Divorced & $6(9.40)$ & $5(11.40)$ & $1(5.00)$ & & & $4(11.40)$ & $2(6.90)$ & & \\
\hline Widowed & $27(42.20)$ & $16(36.40)$ & $11(55.00)$ & & & $12(34.30)$ & $15(51.70)$ & & \\
\hline \multicolumn{10}{|l|}{ KATZ } \\
\hline 0 & $58(90.60)$ & $40(90.90)$ & $18(90.00)$ & 2.729 & 0.435 & $32(91.40)$ & $26(89.70)$ & 2.076 & 0.557 \\
\hline 1 & $4(6.30)$ & $3(6.80)$ & $1(5.00)$ & & & $2(5.70)$ & $2(6.90)$ & & \\
\hline 2 & $1(1.60)$ & 0 & $1(5.00)$ & & & 0 & $1(3.40)$ & & \\
\hline 4 & $1(1.60)$ & $1(2.30)$ & 0 & & & $1(2.90)$ & 0 & & \\
\hline \multicolumn{10}{|l|}{ SPMSQ } \\
\hline 1 & $28(43.80)$ & $19(43.20)$ & $9(45.00)$ & 1.988 & 0.575 & $16(45.70)$ & $12(41.40)$ & 4.646 & 0.200 \\
\hline 2 & $17(26.60)$ & $11(25.00)$ & $6(30.00)$ & & & $7(20.00)$ & $10(34.50)$ & & \\
\hline 3 & $15(23.40)$ & $10(22.70)$ & $5(25.00)$ & & & $8(22.90)$ & $7(24.10)$ & & \\
\hline 4 & $4(6.30)$ & $40(9.10)$ & 0 & & & $4(11.40)$ & 0 & & \\
\hline \multicolumn{10}{|l|}{ MMSE } \\
\hline 1 & $15(23.40)$ & $10(22.70)$ & $5(25.00)$ & 0.388 & 0.824 & $7(20.00)$ & $8(27.60)$ & 1.800 & 0.407 \\
\hline 2 & $16(25.00)$ & $12(27.30)$ & $4(20.00)$ & & & $11(31.40)$ & $5(17.20)$ & & \\
\hline 3 & $33(51.60)$ & $22(50.00)$ & $11(55.00)$ & & & $17(48.60)$ & $16(55.20)$ & & \\
\hline \multicolumn{10}{|l|}{ APGAR Family } \\
\hline 1 & $10(15.60)$ & $7(15.90)$ & $3(15.00)$ & 0.063 & 0.969 & $6(17.10)$ & $4(13.80)$ & 0.299 & 0.861 \\
\hline 2 & $21(32.80)$ & $14(31.80)$ & $7(35.00)$ & & & $12(34.30)$ & $9(31.00)$ & & \\
\hline 3 & $33(51.60)$ & $23(52.30)$ & $10(50.00)$ & & & $17(48.60)$ & $16(55.20)$ & & \\
\hline \multicolumn{10}{|l|}{ BDS } \\
\hline 1 & $19(29.70)$ & $13(29.50)$ & $6(30.00)$ & 3.710 & 0.294 & $11(31.40)$ & $8(27.60)$ & 0.642 & 0.887 \\
\hline 2 & $22(34.40)$ & $12(29.50)$ & $9(45.00)$ & & & $11(31.40)$ & $11(37.90)$ & & \\
\hline 3 & $17(26.60)$ & $12(27.30)$ & $5(25.00)$ & & & $9(25.70)$ & $8(27.60)$ & & \\
\hline 4 & $6(9.40)$ & $6(13.60)$ & 0 & & & $4(11.40)$ & $2(6.90)$ & & \\
\hline \multicolumn{10}{|l|}{ Mini cognitive } \\
\hline 0 & $5(7.80)$ & $5(11.40)$ & 0 & 2.955 & 0.228 & $32(8.60)$ & $2(6.90)$ & 0.331 & 0.847 \\
\hline 1 & $15(23.40)$ & $11(25.00)$ & $4(20.00)$ & & & $9(25.70)$ & $6(20.70)$ & & \\
\hline 2 & $44(68.80)$ & $28(63.60)$ & $16(80.00)$ & & & $23(65.70)$ & $21(72.40)$ & & \\
\hline \multicolumn{10}{|l|}{ DSES } \\
\hline 1 & $7(10.90)$ & $7(15.90)$ & 0 & 4.593 & 0.101 & $5(14.30)$ & $2(6.90)$ & 3.756 & 0.153 \\
\hline 2 & 19 (29.70) & $14(31.80)$ & $5(25.00)$ & & & $13(37.10)$ & $6(20.70)$ & & \\
\hline 3 & $38(59.40)$ & $23(52.30)$ & $15(75.00)$ & & & $17(48.60)$ & $21(72.40)$ & & \\
\hline \multicolumn{10}{|l|}{ Self-efficacy } \\
\hline$M \pm S D$ & $27.88 \pm 6.59$ & $27.34 \pm 6.42$ & $29.05 \pm 6.96$ & -0.962 & 0.340 & $27.11 \pm 6.19$ & $28.79 \pm 7.03$ & -1.015 & 0.314 \\
\hline \multicolumn{10}{|l|}{ DASS 42} \\
\hline$M \pm S D$ & $25.98 \pm 20.05$ & $26.36 \pm 19.33$ & $25.15 \pm 22.05$ & 0.223 & 0.824 & $25.49 \pm 19.83$ & $26.59 \pm 20.64$ & -0.217 & 0.829 \\
\hline \multicolumn{10}{|l|}{ DASS 14} \\
\hline$M \pm S D$ & $9.08 \pm 8.08$ & $10.23 \pm 8.98$ & $6.55 \pm 4.95$ & 2.104 & $0.040^{\mathrm{a}}$ & $9.69 \pm 9.12$ & $8.34 \pm 6.70$ & 0.658 & 0.513 \\
\hline NRS & & & & & & & & & \\
\hline 0 & $27(42.20)$ & $19(43.20)$ & $8(40.00)$ & 1.142 & 0.767 & $14(40.00)$ & $13(44.80)$ & 0.983 & 0.805 \\
\hline 1 & $24(37.50)$ & $17(38.60)$ & $7(35.00)$ & & & $13(37.10)$ & $11(37.90)$ & & \\
\hline 2 & $12(18.80)$ & $7(15.90)$ & $5(25.00)$ & & & $7(20.00)$ & $5(17.20)$ & & \\
\hline 3 & $1(1.60)$ & $1(2.30)$ & 0 & & & $1(2.90)$ & 0 & & \\
\hline MORSE & & & & & & & & & \\
\hline 1 & $26(40.60)$ & $18(40.90)$ & $8(40.00)$ & 1.958 & 0.376 & $12(34.30)$ & $14(48.30)$ & 8.348 & $0.015^{\mathrm{b}}$ \\
\hline 2 & 25 (39.1) & $19(43.20)$ & $6(30.00)$ & & & 19 (54.30) & $6(20.70)$ & & \\
\hline 3 & $13(20.30)$ & $7(15.90)$ & $6(30.00)$ & & & $4(11.40)$ & $9(31.00)$ & & \\
\hline
\end{tabular}


The characteristics of the participants (Table 1) showed that the mean age of the elderly was $71.86 \pm 9.94$ years, and $59.40 \%$ were male. The length of stay of the elderly in institutional rehabilitation was $3.70 \pm 4.44$ years. The elderly in institutional rehabilitation still had functional family based on APGAR scores (51.60\%) and mild depression (34.40\%). Almost $68.80 \%$ of the elderly people had dementia, while $59.40 \%$ of them had regularly experienced spiritual activities. Table 1 shows that there was a correlation between DASS-14 and systolic hypertension $(t=2.104 ; p=0.040)$. Meanwhile, there was also a correlation between Morse risk fall and diastolic hypertension $\left(\chi^{2}=8.348 ; p=0.015\right)$.

Multiple linear regression using the stepwise method determined the explanatory variables predictive of the elderly's self-efficacy with systolic hypertension. The last model ( $\mathrm{Ta}$ ble 2) shows spiritual activity, length of stay, education, occupation before entering the institutional rehabilitation, and dementia as significant predictors of self-efficacy of the elderly people with systolic hypertension $(p<0.05)$.

Table 2. Factors which influenced self-efficacy of the elderly people with systolic hypertension in a nursing home $(n=20)$

\begin{tabular}{|c|c|c|c|c|c|c|c|c|c|}
\hline Variable & Model 1 & Model 2 & Model 3 & Model 4 & Model 5 & Model 6 & Model 7 & Model 8 & Model 9 \\
\hline Marital status & - & & & & & & & & \\
\hline MORSE & 0.099 & & & & & & & & \\
\hline APGAR & 0.773 & 0.791 & & & & & & & \\
\hline MMSE & -0.606 & -0.609 & -0.461 & & & & & & \\
\hline DASS 14 & -0.080 & -0.076 & -0.110 & -0.118 & & & & & \\
\hline Gender & -4.048 & -4.087 & -4.201 & -4.264 & -3.892 & & & & \\
\hline DASS 42 & -0.075 & -0.075 & -13.437 & -0.065 & -0.084 & -0.044 & & & \\
\hline Ethnicity & -7.014 & -7.042 & -7.119 & -7.048 & -6.607 & -5.657 & -5.877 & & \\
\hline BDS & 5.603 & 5.623 & 5.590 & 5.484 & 6.070 & 5.657 & 5.168 & 3.272 & \\
\hline KATZ & 16.509 & 16.644 & 16.172 & 15.700 & 16.226 & 11.668 & 10.072 & 5.728 & 6.110 \\
\hline Age & 0.269 & 0.272 & 0.241 & 0.234 & 0.248 & 0.191 & 0.202 & 0.241 & 0.217 \\
\hline NRS & -13.890 & -13.917 & -13.437 & -13.108 & $-13.466^{\mathrm{a}}$ & $-10.593^{a}$ & $-10.497^{\mathrm{a}}$ & -7.012 & -5.970 \\
\hline SPMSQ & -13.461 & -13.563 & -13.098 & -13.060 & -12.686 & $-9.283^{\mathrm{a}}$ & $-9.154^{\mathrm{a}}$ & -7.018 & -6.677 \\
\hline DESS & 7.099 & 7.163 & 7.386 & 7.245 & 6.661 & 4.876 & 4.810 & 4.881 & $6.430^{\mathrm{a}}$ \\
\hline Length of stay & 1.452 & 1.455 & 1.449 & 1.431 & 1.348 & 1.741 & $1.975^{\mathrm{a}}$ & $2.039^{\mathrm{a}}$ & $2.354^{\mathrm{a}}$ \\
\hline Education & -10.495 & -10.547 & -10.234 & $-10.144^{a}$ & $-9.911^{\mathrm{a}}$ & $-10.336^{b}$ & $-10.341^{b}$ & $-10.217^{b}$ & $-11.070^{b}$ \\
\hline Occupation before entrance & -20.714 & -20.769 & -10.234 & $-20.239^{a}$ & $-19.450^{\mathrm{a}}$ & $-18.881^{b}$ & $-19.729^{b}$ & $-20.130^{b}$ & $-21.162^{b}$ \\
\hline Mini Cog & -12.739 & -12.769 & -12.704 & -12.658 & -12.474 & $-18.290^{b}$ & $-19.804^{b}$ & $-17.415^{b}$ & $-18.211^{b}$ \\
\hline$R$ Square & 0.891 & 0.891 & 0.891 & 0.890 & 0.889 & 0.875 & 0.869 & 0.823 & 0.795 \\
\hline Constant & 76.016 & 76.154 & 77.579 & 77.554 & 73.532 & 67.415 & 66.856 & 51.794 & 56.407 \\
\hline
\end{tabular}

Multiple linear regression using the stepwise method determined the explanatory variables predictive of the elderly's self-efficacy with diastolic hypertension. The last model (Table 3) shows daily activities, risk of falling, pain, depression, anxiety and stress as significant predictors of elderly people's self-efficacy with diastolic hypertension $(p<0.05)$.

\section{Discussion}

\section{Prevalence of hypertension among the elderly in institution-based rehabilitation}

The current study found that the prevalence of systolic and diastolic hypertension among the elderly is low compared to the hypertension of elderly people in Shanghai (Yang et al., 2017), although the prevalence of elders with hypertension is higher than in the Indonesian basic health survey (Badan Penelitian dan Pengembangan Kesehatan, 2013). The difference in hypertensive outcomes among the elderly people may be due to differences in the setting of the study site and the character- istics of the elderly people. The current research setting was an institution-based rehabilitation centre in Indonesia; it is a unit owned by the Social Service and Social Welfare, which is limited in health service management because the main focus of the activity is the daily social activities of the elderly people. This will affect the health problems of the elderly people. The results of this study are also consistent with previous research, suggesting that institutionalization of the elderly contributes to various problems of those living in nursing homes (Sombateyotha et al., 2016). Therefore, modification of the form of nursing action of the institutionalized elderly persons should focus on enhancing their self-efficacy to control blood pressure, so that hypertension among the elders can be comprehensively and holistically managed.

\section{Factors related to the self-efficacy of elderly people with systolic hypertension}

There are five factors related to the self-efficacy of elderly people with systolic hypertension, including education, occupation before entering institutional rehabilitation, spiritual ac- 


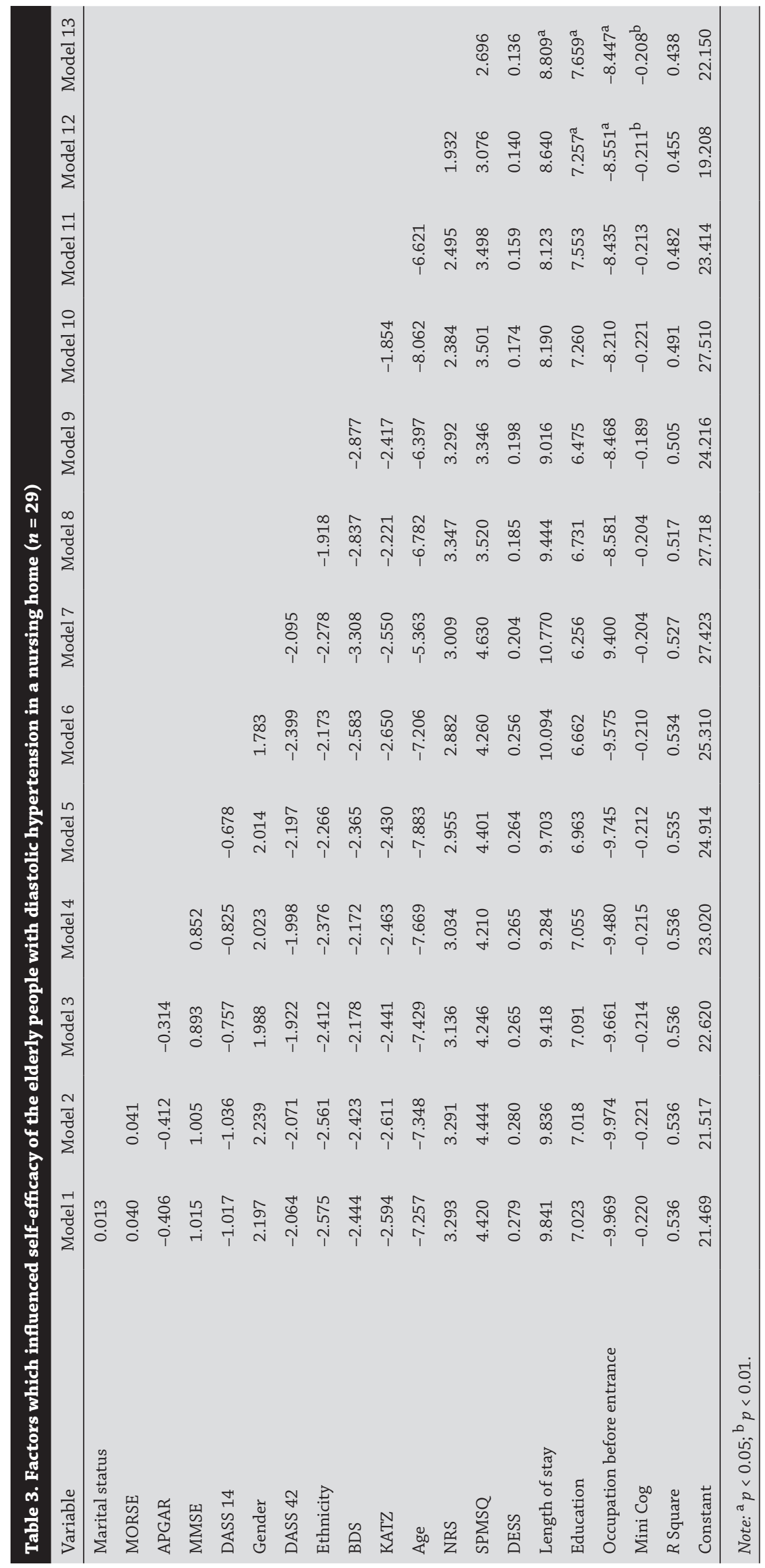


tivities, length of stay, and dementia. In this study, education is related to the self-efficacy of the elderly people with systolic hypertension, which is consistent with previous studies indicating that lower education is linked with uncontrolled hypertension among elderly people (Yang et al., 2017). These results suggest that education contributes to the understanding of health information and the health literacy of the elderly.

The findings illustrate that the occupation of the elderly people before entering the institution-based rehabilitation correlated with the self-efficacy of the elders with systolic hypertension. The results of this study are similar to those of previous studies, indicating that the occupations will affect their health literacy, self-efficacy and their attitude to hypertension treatment program (An and Park, 2016). This result may indicate, that there is a correlation between elderly people's previous occupation and subsequent physiological condition. The physiological concept of wear and tear during their life experiences are related to type of work; each type will have a different impact on the health status of the elderly people, especially their blood pressure. Therefore, the severity of hypertension will depend on the type of work prior to retirement and living in institution-based rehabilitation.

Spiritual activities regarding DESS measurement correlated with the self-efficacy of systolic hypertension of the elderly people. This finding is consistent with previous research indicating that religious programs based on Islam or spiritual wellbeing in elderly patients with hypertension (Moeini et al., 2016) influenced the quality of their life (Susanto and Widayati, 2018). These results suggest that a spiritual activity program should be developed in institution-based rehabilitation based on the health beliefs of elderly people to improve self-efficacy.

Our findings show that the length of stay in institution-based rehabilitation correlates with the self-efficacy of the elderly people with systolic hypertension. This is similar to previous research results that suggest hypertension was associated with hospitalization. Therefore, community-based rehabilitation is the best practice for elderly people to improve their activity, daily living and cognitive functions (Moeini et al., 2016). This suggests that involving the elderly in family and/or community-based rehabilitation is an option for improving their self-efficacy in controlling blood pressure.

Others results showed that dementia is correlated with the self-efficacy of the elderly people with systolic hypertension. This is consistent with previous studies on self-efficacy, dementia and hypertension in elderly people (Crellin et al., 2014; Harmell et al., 2011). These findings could indicate that the cognitive function of elderly people with dementia will influence their perception in modifying their health behavior in achieving self-efficacy in controlling blood pressure. Therefore, attention should be paid to the management of dementia in order to improve self-efficacy in the quality of life of the elderly people with hypertension.

\section{Factors related to self-efficacy of elderly people with diastolic hypertension}

In this study, daily activities, risk of falling, pain, depression, anxiety and stress were found to be associated with self-efficacy of the elderly people with diastolic hypertension. This research has shown that the daily activities of elderly people may correlate with self-efficacy on diastolic hypertension. Consistent with previous research, this self-efficacy, along with functional daily activities are correlated to achieving successful aging (Seeman et al., 1999). This may be explained by the level of independence of the elderly in performing basic daily activities. The results of this study suggest that the elderly still maintain the functional status of independence in meeting basic needs. So, the elderly can establish self-efficacy to control blood pressure.

Our findings showed that the risk of falling among the elderly is associated with self-efficacy on diastolic hypertension. Similar to previous research, fall-risk is related to self-efficacy in daily activities (Hellström et al., 2013). This can be because self-efficacy has a large influence on the physical activities of the elderly (McAuley et al., 2013). The results of this study suggest that there is a need to provide adequate physical activities to the elderly to prevent the risk of falling, so that the elders can achieve the self-efficacy to control their blood pressure.

In this study, elderly people with pain condition are related to self-efficacy of diastolic hypertension, which is consistent with previous research suggesting that extensive pain was correlated with low self-efficacy (Rahman et al., 2008). This could be because the intensity of physical and psychological pain affects comfort, which simultaneously affects the health status of the elderly people. Therefore, good pain management during the aging process is needed so that the elderly can increase the value of self-efficacy in blood pressure control.

The findings of the current study indicate that depressive anxiety and stress in the elderly are correlated with self-efficacy of diastolic hypertension. These results are consistent with previous research; the depressed status of elderly people is associated with adherence of medication hypertension (Son and Won, 2017). This finding may be explained by the fact, that hypertension is a chronic disease which affects the mental health of elders and can lead to depression (Rueda and Pérez-García, 2006). To solve bad mental health of elders, group therapy in IRB and nursing intervention should be initiated.

Our research results also indicate the prevalence of hypertension and factors affecting self-efficacy in elderly people with hypertension living in institution-based rehabilitation in Indonesia. The result of this research is the best study in older nursing in Indonesia, because to our knowledge of identification of self-efficacy hypertension in elderly in institutional rehabilitation in Indonesia is rarely. This study provides new evidence that signifies the current burden of hypertension and the critical factors of self-efficacy for uncontrolled hypertension among the elderly people in institution-based rehabilitation.

\section{Limitations}

The limitations of this study include the cross-sectional nature of the study design, which resulted in associations being found among the variables, rather than causal conclusions. There is a further limitation regarding the measured prevalence of the elderly people with hypertension and factors of self-efficacy, which may be different from that identified in other studies based on sample size and the kind of management of health care in the institution-based rehabilitation. However, regarding this research, we suggest family or community based rehabilitation, which is better for maintaining the self-efficacy of elderly people in terms of maintaining their blood pressure.

\section{Conclusions}

Factors related to self-efficacy among elderly people with systolic hypertension include: education, occupation before entering institution-based rehabilitation, spiritual activity, length of stay, and dementia. Meanwhile, the self-efficacy of elderly people with diastolic hypertension is associated with daily activities, risk of falling, pain, depression, anxiety and 
stress. The study results suggest that health-promotion programs on the management of the health behavior of elderly that is based on the characteristics of institution-based rehabilitation in Indonesia is needed to modify factors of hypertension among elderly people. The health promotion program should be developed to keep blood pressure in order. This program should concern the self-efficacy of elderly people to prevent hypertension among elderly people. Meanwhile, family or community based rehabilitation for the elderly could become an alternative solution for the improvement of the health status of the elderly based on the Indonesian context.

\section{Ethical clearance}

The study has been approved by the Ethical Committee Review Board of Indonesia of the Faculty of Nursing, University of Jember.

\section{Conflict of interests}

The authors have no conflict of interests to disclose.

\section{Acknowledgements}

The authors would like to thank the Faculty of Nursing and the Department of Research and Community Engagement of the University of Jember for the funding of Research Group Health and Wellness for Elderly. They would also like to thank the intership students from the subject of Gerontic Nursing for collecting the data, who practiced in Elderly Rehabilitation of Bondowoso.

\section{Prevalence hypertenze a prediktivní faktory sebeúčinnosti u starších lidí s hypertenzí v institucionální rehabilitaci v Indonésii}

\section{Souhrn}

Cíl: Identifikace faktorů hypertenze u starších lidí by měla vytvořit vhodné ošetřovatelské intervence pro zlepšení úrovně nezávislosti pacientů pomocí modifikace faktorů, které ovlivňují krevní tlak u seniorů s hypertenzí. Cílem této studie je vyšetřit prevalenci hypertenze a prediktivní faktory nezávislosti u starších lidí s hypertenzí v institucionální rehabilitaci (IBR) v Indonésii. Metodika: Byla provedena průřezová studie IBR zahrnující 64 náhodně vybraných starších lidí. Údaje z výzkumu byly shromážděny pomocí strukturovaného dotazníku a standardního protokolu, pomocí stetoskopu a sfygmomanometru pro měření krevního tlaku. Data byla poté analyzována pomocí deskriptivní a srovnávací statistiky, stejně jako multivariační lineární regresní analýzy. Výsledky: Prevalence systolické a diastolické hypertenze u starších pacientů, kteří žili v IBR, činila 31,30 \% a 45,30 \%. Prediktory nezávislosti starších osob s ohledem na systolickou hypertenzi byly duchovní aktivity, délka pobytu, vzdělání, zaměstnání starších osob před rehabilitací a demence, zatímco denní aktivity, riziko pádu, bolest a deprese, úzkost a stres se stávají významnými prediktory nezávislosti u starších lidí s diastolickou hypertenzí.

Závěr: Tato studie poskytuje nové důkazy, které poukazují na současné zatížení způsobené hypertenzí a kritické faktory nezávislosti pro nekontrolovanou hypertenzi mezi staršími pacienty v IBR. Studie naznačuje, že by programy podpory zdraví měly být vyvinuty tak, aby modifikovaly faktory hypertenze u starších pacientů v IBR v Indonésii.

Klíčová slova: krevní tlak, senior, hypertenze, institucionální rehabilitace, nezávislost

\section{References}

1. An N, Park IS (2016). The Effect of Health Literacy and Selfefficacy on Treatment Adherence of Hypertensive Elders. Indian J Sci Technol 9. DOI: 10.17485/ijst/2016/v9i25/97205.

2. Badan Penelitian dan Pengembangan Kesehatan (2013). Riset Kesehatan Dasar. Jakarta.

3. Beck A., Ward CH, Mendelson M, Mock J, Erbaugh J (1961). An inventory for measuring depression. Arch Gen Psychiatry 1: 561-571. DOI: 10.1017/CBO9781107415324.004.

4. Borson S, Scanlan JM, Chen P, Ganguli M (2003). The Mini$\mathrm{Cog}$ as a screen for dementia: Validation in a population-based sample. J Am Geriatr Soc 51: 1451-1454.

5. Crellin NE, Orrell M, McDermott O, Charlesworth G (2014). Self-efficacy and health-related quality of life in family carers of people with dementia: a systematic review. Aging Ment Health 18: 954-969. DOI: 10.1080/13607863.2014.915921.

6. Currie G, Delles C (2018). Blood pressure targets in the elderly. J Hypertens 36: 234-236. DOI: 10.1097/ HJH.0000000000001576.

7. Douglas BM, Howard EP (2015). Predictors of self-management behaviors in older adults with hypertension. Adv Prev Med Article ID: 960263. DOI: 10.1155/2015/960263.

8. Elder K, Ramamonjiarivelo Z, Wiltshire J, Piper C, Horn WS, Gilbert KL, et al. (2012). Trust, medication adherence, and hypertension control in Southern African American men. Am J Public Health 102: 2242-2245. DOI: 10.2105/ AJPH.2012.300777.

9. Eom SO, Lee I (2017). The Effect of Health Coaching Programs on Self-Efficacy, Health Behaviors, and Quality of Life in Hypertensive People Living in Poverty. J Korean Acad Nurs 47: 380. DOI: 10.4040/jkan.2017.47.3.380.

10. Friedberg JP, Rodriguez MA, Watsula ME, Lin I, Wylie-Rosett J, Allegrante JP, et al. (2015). Effectiveness of a tailored behavioral intervention to improve hypertension control: Primary outcomes of a randomized controlled trial. Hypertension 65: 440-446. DOI: 10.1161/HYPERTENSIONAHA.114.03483.

11. Harmell AL, Mausbach BT, Roepke SK, Moore R, Känel R, Patterson TL, et al. (2011). The Relationship between self-efficacy and resting blood pressure in Spousal Alzheimer's Caregivers. Br J Health Psychol 16: 317-328. DOI: 10.1348/135910710X504932.

12. Hellström K, Sandström M, Heideken Wågert P, Sandborgh M, Söderlund A, Thors Adolfsson E, Johansson A-Ch (2013). Fall-related self-efficacy in instrumental activities of daily living is associated with falls in older communityliving people. Phys Occup Ther Geriatr 31: 128-139. DOI: 10.3109/02703181.2013.792912.

13. Irwan AM, Kato M, Kitaoka K, Ueno E, Tsujiguchi $H$, Shogenji M (2016). Development of the salt-reduction and efficacy-maintenance program in Indonesia. Nurs Heal Sci 18: 519-532. DOI: 10.1111/nhs.12305. 
14. Jewpattanakul Y (2012). Strengthening Self-efficacy of the Elderly with Hypertension for Exercise: Roles of Family Members. J Nurs Sci 30: 81-90.

15. Krebs EE, Carey TS, Weinberger M (2007). Accuracy of the pain numeric rating scale as a screening test in primary care. J Gen Intern Med 22: 1453-1458. DOI: 10.1007/s11606-007-0321-2.

16. Lee E, Park E (2017). Self-care behavior and related factors in older patients with uncontrolled hypertension. Contemp Nurse 0: 1-15. DOI: 10.1080/10376178.2017.1368401.

17. Li SX, Zhang L (2013). Health behavior of hypertensive elderly patients and influencing factors. Aging Clin Exp Res 25: 275-281. DOI: 10.1007/s40520-013-0051-8.

18. Lovibond SH, Lovibond PF (1995). Manual for the Depression Anxiety Stress Scales. Sydney, Psychology Foundation. DOI: 10.1097/HTR.0000000000000250.

19. Martin MY, Person SD, Kratt P, Prayor-Patterson H, Kim Y, Salas M, Pisu M (2008). Relationship of health behavior theories with self-efficacy among insufficiently active hypertensive African-American women. Patient Educ Couns 72: 137-145. DOI: 10.1016/j.pec.2008.02.012.

20. McAuley E, Szabo A, Gothe N, Olson EA (2013). Self-efficacy: Implications for Physical Activity, Function, and Functional Limitations in Older Adults Edward. Am J Lifestyle Med 5: 1-15. DOI: $10.1177 / 1559827610392704$.

21. Moeini M, Sharifi S, Kajbaf M (2016). Effect of Islambased religious program on spiritual wellbeing in elderly with hypertension. Iran J Nurs Midwifery Res 21: 566. DOI: $10.4103 / 1735-9066.197683$.

22. Morse J, Black C, Oberle K, Donahue P (1989). Falls : Morse Fall Scale. Soc Sci Med 28: 81-86.

23. Pfeiffer E (1975). A Short Portable Mental Status Questionnaire for the Assessment of Organic Brain Deficit in Elderly Patients. J Am Geriatr Soc 23: 433-441.

24. Rahman A, Reed E, Underwood M, Shipley ME, Omar RZ (2008). Factors affecting self-efficacy and pain intensity in patients with chronic musculoskeletal pain seen in a specialist rheumatology pain clinic. Rheumatology (Oxford) 47: 18031808. DOI: $10.1093 /$ rheumatology/ken377.

25. Ridha B, Rossor M (2005). The mini mental state examination. Pract Neurol 5: 298-303. DOI: 10.1111/j.14747766.2005.00333.x.

26. Rueda B, Pérez-García AM (2006). A prospective study of the effects of psychological resources and depression in essential hypertension. J Health Psychol 11: 129-140. DOI: $10.1177 / 1359105306058868$.

27. Schwarzer R, Jerusalem M (1995). General Self Efficacy scale. In: Weinman J, Wright $S$, Johnston M. Measures in health psychology: A user's portfolio. Causal and control beliefs. Windsor, NFER-NELSON, pp. 35-37.
28. Seeman TE, Unger JB, McAvay G, Mendes de Leon CF (1999). Self-efficacy beliefs and perceived declines in functional ability: MacArthur studies of successful aging. J Gerontol B Psychol Sci Soc Sci 54: P214-P222. DOI: 10.1093/geronb/54B.4.P214.

29. Smilkstein G (1978). The Family APGAR: A proposal for family function test and its use by physicians. J Fam Pract 6: 12311239.

30. Sol BGM, Graaf Y van der, Bijl JJ van der, Goessens NBG, Visseren FLJ (2006). Self-efficacy in patients with clinical manifestations of vascular diseases. Patient Educ Couns 61: 443-448. DOI: 10.1016/j.pec.2005.05.011.

31. Sombateyotha K, Pichainarong N, Schelp F-P, Homchampa P (2016). Effect of Institution-Based Management for Elderly Health Promotion Program in Northeastern Thailand. Southeast Asian J Trop Med Public Health 47: 1062-1088.

32. Son Y-J, Won MH (2017). Depression and medication adherence among older Korean patients with hypertension: Mediating role of self-efficacy. Int J Nurs Pract 23: e12525. DOI: 10.1111/ ijn.12525.

33. Susanto T, Widayati N (2018). Quality of life of elderly tobacco farmers in the perspective of agricultural nursing: a qualitative study. Working with Older People 9: 166-177. DOI: 10.1108/ WWOP-01-2018-0002.

34. Wallace BM, Shelkey M (2000). Katz Index of Independence in Activities of Daily Living. Geriatr Nurs 21: 109. DOI: 10.1016/ S0197-4572(00)70015-2.

35. Warren-Findlow J, Seymour RB, Huber LRB (2012). The association between self-efficacy and hypertension self-care activities among African American adults. J Community Health 37: 15-24. DOI: 10.1007/s10900-011-9410-6.

36. Wise FM, Harris DW, Olver JH (2017). The DASS-14 : Improving the Construct Validity and Reliability of the Depression, Anxiety, and Stress Scale in a Cohort of Health Professionals. J Allied Health 46: 85-90.

37. Yang SO, Kim SJ, Lee SH (2016). Effects of a South Korean Community-Based Cardiovascular Disease Prevention Program for Low-Income Elderly with Hypertension. J Community Health Nurs 33:154-167. DOI: 10.1080/07370016.2016.1191872.

38. Yang ZQ, Zhao Q, Jiang P, Zheng SB, Xu B (2017). Prevalence and control of hypertension among a Community of Elderly Population in Changning District of Shanghai: A cross-sectional study. BMC Geriatr 17: 1-9. DOI: 10.1186/s12877-017-0686-y.

39. Yu SJ, Song M, Lee Y (2001). The Effects of Self-efficacy Promotion and Education Program on Self-efficacy, Self-Care Behavior, and Blood Pressure for Elderly Hypertensives. J Korean Acad Adult Nurs 13: 108-122. 